\title{
Biosynthesis and Characterization of Copper Oxide Nanoparticles using Cimin Grape (Vitis vinifera cv.) Extract
}

\author{
Demet DEMIRCI GULTEKIN"1, Hayrunnisa NADAROGLU ${ }^{2,3}$, \\ Azize ALAYLI GUNGOR ${ }^{3,4}$, Nurhan HORASAN KISHALI ${ }^{5}$
}

\footnotetext{
${ }^{1}$ Ataturk University, Aşkale Vocational Training School, Dep. of Metallurgical Program, 25500, Erzurum, Turkey ${ }^{2}$ Ataturk University, Erzurum Vocational Training School, Dep. of Food Technology, 25240 Erzurum, Turkey

${ }^{3}$ Ataturk University, Faculty of Engineering, Dep. of Nano-Science and Nano-Engineering, 25240 Erzurum, Turkey

${ }^{4}$ Ataturk University, Erzurum Vocational Training School, Dep. of Chemical Technology, 25240 Erzurum, Turkey

${ }^{5}$ Ataturk University, Faculty of Science, Department of Chemistry, 25240 Erzurum, Turkey
}

Received: 02 May 2017 - Revised: 23 June 2017 - Accepted: 12 July 2017

\begin{abstract}
Nowadays, nanoparticle synthesis has been a very important research area because of the wide use of nanoparticles in many fields. Green synthesis is one step ahead of other synthesis methods due to both cost reduction in production and environmentally friendly approach. For these reasons, we chose green synthesis method which is nature friendly in our research. In this study, it was aimed synthesis of copper nanoparticles by the green synthesis method using the water extract of Erzincan Cimin grape (Vitis vinifera cv. Black plum) from $0.1 \mathrm{M} \mathrm{CuCl}_{2} .2 \mathrm{H}_{2} \mathrm{O}$ in the reaction medium. Then, optimum conditions for the green synthesis reaction had been determined and product optimization of copper nanoparticles was made. Optimum conditions for synthesis were measured at a wavelength of $355 \mathrm{~nm}$ (for $\mathrm{CuO}$ nanoparticles). It was observed that the best synthesis reaction was occurred at $\mathrm{pH} 5$, temperature $60{ }^{\circ} \mathrm{C}, 0.05 \mathrm{M}$ metal ion concentration and within the 60 minutes. The characterization of the $\mathrm{CuO}$ nanoparticles was obtained then was characterized using spectroscopic techniques such as UV-VIS, FTIR, XRD and SEM. When the chromatograms obtained using these techniques were examined, it was understood that 25-50 nm morphologically homogeneous nanoparticles were synthesized. Due to the new physical and chemical properties of obtained copper nanoparticles using a cost-effective and environmentally friendly green synthesis method using water extract of Erzincan Cimin Grape; it was thought that in many areas (optical, biosensors, etc.) could be used.
\end{abstract}

Keywords: Copper(II)oxide NPs, Green synthesis, Nanotechnology

\section{INTRODUCTION}

Green synthesis is an important application that it is preferred by many environmentally friendly approaches like chemistry. Nowadays, the synthesis of nanoparticles with green synthesis has resulted in green nanosynthesis. Nature and human-friendly nanomaterial synthesis is performed by this method. The most important advantage of this method is that the harmful toxic chemicals are either not used at all or the less harmful ones are used. The reaction

\footnotetext{
*Corresponding Author E-mail: demet.gultekin@atauni.edu.tr
} 
media in green nanosynthesis can be live in tissue, cells, organisms or extracts from them like enzymes, carbohydrates, lipids and proteins. There are three types commonly used [1-3].

First, enzymes are used in green nanosynthesis since they now have a wide range of chemical reaction forces. Secondly, microorganisms (bacteria, yeast or mold) are also important reaction factors for green synthesis reactions. Finally, other used components are plant or animal extracts. Plants and extracts have been preferred due to their advantages of growing in short time, abundant quantity and storage. [4-6]. By some research groups, the synthesis of silver nanoparticles and gold nanoparticles have been achieved using plant extracts Nephelium lappaceum L. and Plectranthus amboinicus [7-8].

It comes from the historical sources that grape fruit was known and consumed 6.000 years ago by the Egyptians. In the whole grape and seeds, there are commonly phenolic compounds, antioxidants, organic acids, fatty acids, carbohydrates and water. Nowadays grape plant; proteins and biomolecules have begun to be used in metal nanoparticle synthesis due to their reducing properties [1-3].

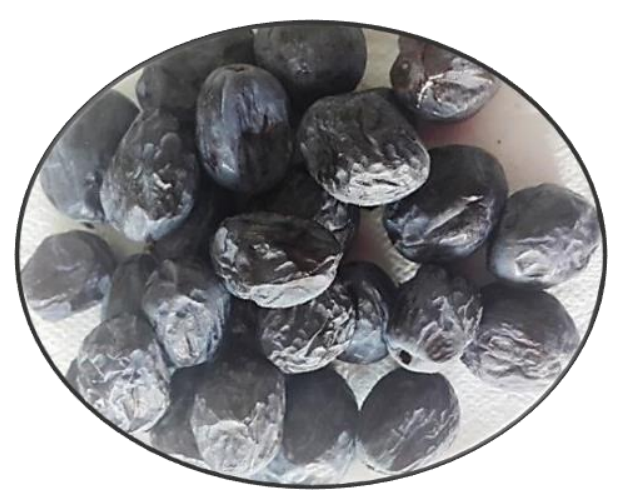

Figure 1. Cimin grape (Vitis vinifera, variety Cimin)

Nanoparticles have entered into many fields, mainly energy storage, textile, paint industry and health field. Moreover, it is noteworthy that the share of nanotechnology in these areas has increased day by day. Nano materials show different properties according to the non-nano size. This situation varies depending on the particle size. All metal nanoparticles in which copper oxide are synthesized have different optical, conductivity, antimicrobial and thermal properties than non-nanoscale metal oxides. For this reason, metal oxide nanoparticles are found in different application areas. They have extensive range of uses, such as fuel cells, catalysts, magnetic recording, optoelectronic, magnetic fluid, materials, photovoltaic supplies, pigments, and sensors [7-9].

Because of the unique properties (physicochemical, optical, catalysis, magnetic, electronic and antimicrobial) of metal oxide nanoparticles in their dimensions below $100 \mathrm{~nm}$, the number of studies directed to them has also increased significantly. There are now numerous methods for synthesizing nanoparticles with the desired properties. However, most of these methods are expensive and the synthesis conditions are heavy. It also contains many elements that can create a biological threat to the environment. Copper oxide nanoparticles, which have become of great interest since the late 20th century due to their catalytic, optical and electrical properties, in terms of their lubricants and catalysts in the chemical industry, and conductivity properties, they have a very wide application network in the electricity and the chemical sector [10-11]. Because copper oxide nanoparticles are semiconductor, they are used in catalysts, gas sensors and photovoltaic cells. Because of its electronic and magnetic properties, it is one of the basic components of superconducting materials [12]. 
In this study, synthesis of copper oxide nanoparticles was aimed. An easy, non-toxic and rapid method for green synthesis has been investigated. For this reason, easily obtained, nontoxic, renewable grape fruit can be chosen to be synthesis material.

\section{EXPERIMENTAL}

\subsection{Chemical and reagents}

Copper(II)chloride $\left(\mathrm{CuCl}_{2} .2 \mathrm{H}_{2} \mathrm{O}\right), \quad$ Sodium acetate $\left(\mathrm{NaCH}_{3} \mathrm{COO}\right), \quad$ Tris $\left(\left(\mathrm{HOCH}_{2}\right)_{3} \mathrm{CNH}_{2}\right)$, Sodium carbonate $\left(\mathrm{Na}_{2} \mathrm{CO}_{3}\right)$, Sodium hydroxide $(\mathrm{NaOH})$, Hydrochloric acid $(\mathrm{HCl})$ were purchased from Sigma-Aldrich $\mathrm{GmbH}$, (Sternhe I Germany). The other chemicals were obtained from Merck. Deionized water was used to prepare all solutions.

\subsection{Preparation of Cimin Grapes Extract}

Grape extracts containing a big amount of polyphenols. The grape extracts may a significant source of natural and economical antioxidants and it can be used as a reducing agent during metal nanoparticle preparation (13). For this reasons, The Cimin grape (Vitis vinifera $c v$.), used in this study was collected from Üzümlü providence in Erzincan City, Turkey at the season August-September, was identified with the help of taxonomists. They were stored in a cold air store until working. The Cimin grape was separated from branches and washed with deionized water three times for removing their dust. The grape $(250 \mathrm{~g})$ was thoroughly shattered to form a homogeneous mixture in a blender, along with a $250 \mathrm{~mL}$, deionized water. The mixture was centrifuged at $5.000 \mathrm{xg}$ for $10 \mathrm{~min}$ and the supernatant was used for in the green synthesis reaction.

\subsection{Green Synthesis Reaction Medium}

It was prepared $0.1 \mathrm{M} \mathrm{CuCl}_{2} \cdot 2 \mathrm{H}_{2} \mathrm{O}$ with deionized water for nanoparticle synthesis. 10 $\mathrm{mg} / \mathrm{mL}$ grape extract was added reaction mixture. Green synthesis medium was mixed with a magnetic stirrer at $200 \mathrm{xg}$ for $3 \mathrm{~h}$.

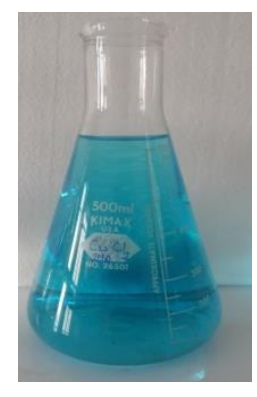

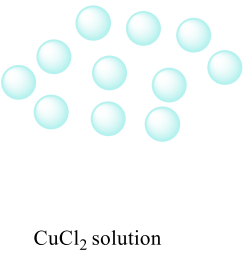

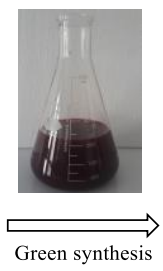

$\mathrm{CuCl}_{2}$ solution

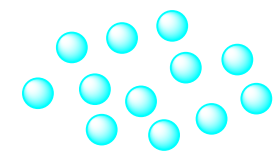

CuO Nanoparticles
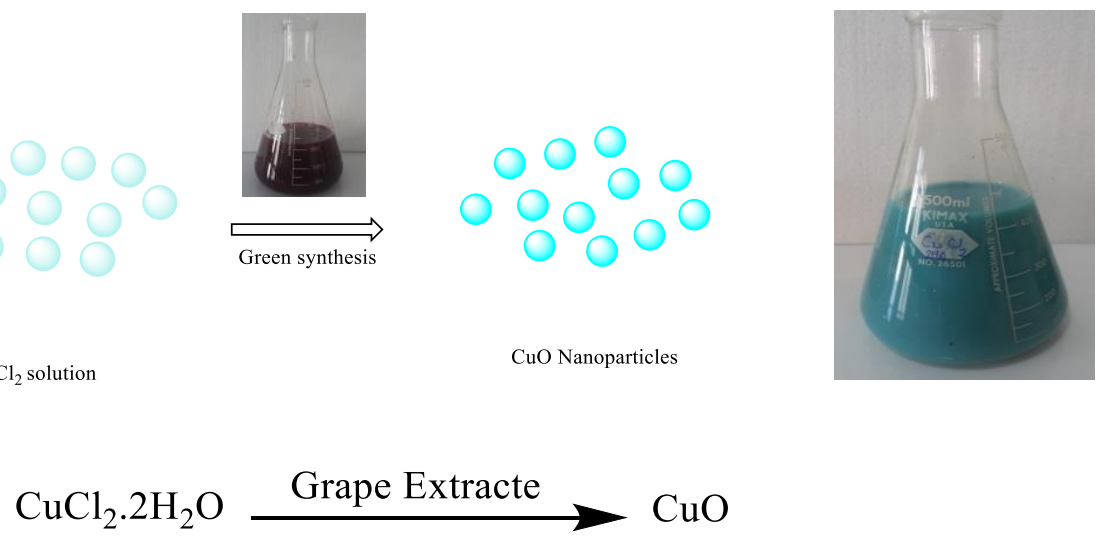

Figure 2. Grape extract and $0.1 \mathrm{M} \mathrm{CuCl}_{2} \cdot 2 \mathrm{H}_{2} \mathrm{O}$ was used for nanoparticle synthesis

$\mathrm{Cu}^{2+}$ with reacted with the grape extract was transformed into $\mathrm{Cu}^{+}$biochemical reduction and it became nanoparticle as copper(I)oxide together with the oxygen molecules in the environment. $\mathrm{Cu}^{2+}$ which reacts with the resulting grape extract were converted to $\mathrm{Cu}^{+}$by a biochemical reduction. When the reaction started the entire medium was clear blue. The formation of red-brown precipitate of the obtained $\mathrm{Cu}_{2} \mathrm{O}$ nanoparticles was observed on the lower surface of the reaction chamber. $\mathrm{Cu}^{+}$together the oxygen molecules in the air have become copper(II)oxide nanoparticles. Blurred blue Copper(II)oxide nanoparticles were synthesized by a bio oxide-reduction method [14]. 
For wavelength scanning, the maximum wavelength was determined by scanning the wavelength between 190-800 $\mathrm{nm}$ after treatment with $1 \mathrm{M} \mathrm{CuCl} 2.2 \mathrm{H}_{2} \mathrm{O}$ solution with Cimin grape extract for 3 hours. Nano copper(II)oxide formation was observed during this time. UVVis spectrometer was used for this purpose [15-16].

\subsection{Optimization of Green Synthesis Reaction}

\subsubsection{Optimization of Green Synthesis Reaction}

For determination of the optimum contact time, samples were spectrophotometrically measured between 0 and 180 min with 10-minutes intervals.

\subsubsection{Determination of optimum $\mathrm{pH}$}

Synthesis of the $\mathrm{CuO}$ nanoparticles was performed at $\mathrm{pH} 3-5$, an acetate buffer at $\mathrm{pH} 5$ 8, a phosphate buffer at $\mathrm{pH} 8-9$, Tris buffer and at $\mathrm{pH} 10$, a carbonate buffer. The $\mathrm{pH}$ was adjusted using $0,1 \mathrm{~N} \mathrm{HCI}$ and $0,1 \mathrm{~N} \mathrm{NaOH}$. The values of absorbance were determined with an $\mathrm{UV}-\mathrm{Vis}$ spectrophotometer.

\subsubsection{Determination of optimum temperature}

Green synthesis of the $\mathrm{CuO}$ nanoparticles was carried out separately from $5{ }^{\circ} \mathrm{C}$ to $80{ }^{\circ} \mathrm{C}$ respectively, and the changes in absorbance in the samples were measured by a UV-Vis spectrophotometer (Epoch Biotech nanoDrop Spectrophotometer).

\subsubsection{Determination of optimum concentration of metal ion}

Green synthesis of the $\mathrm{CuO}$ nanoparticles was performed using a copper (II) chloride solution between $4.10^{-1}$ to $1.25 .10^{-2} \mathrm{M}$ and the absorbance changing of the examples was measured by a UV-Vis spectrophotometer at $355 \mathrm{~nm}$.

\subsection{Characterization of $\mathrm{CuO}$ Nanoparticles}

The synthesized $\mathrm{CuO}$ nanoparticles were characterized by scanning at a range of 190 $800 \mathrm{~nm}$ by using an UV-VIS spectrophotometer (Epoch Biotech nanoDrop Spectrophotometer). For investigating features parameters of examples, XRD (X-Ray Diffractometer), SEM (Scanning Electron Microscope) (Sigma 300, SEM Zeiss, Germany) and EDX (energy dispersive X-ray) were used as exploration tools. Structural and morphological studies were carried out by XRD (PANalytical, Empyrean, Netherlands) using $\mathrm{Cu} \mathrm{K \alpha}(\lambda=1.5405 \AA)$ radiation. And they were performed at DAYTAM (Eastern Anatolian High Technology Applications and Research Center).

\section{RESULTS and DISCUSSIONS}

Cimin grape $(10 \mathrm{mg} / \mathrm{mL})$ was added in sample of copper (II) chloride solution $\mathrm{CuCl}_{2} .2 \mathrm{H}_{2} \mathrm{O},(0.1 \mathrm{M})$ and incubated and mixed in a closed space for 1 hours. The reaction mixture was changed from blue to intense blue and at the bottom red-brown, which indicates the presence of copper(II)oxide nanoparticles. The maximum absorbance of synthesized copper(II)oxide nanoparticles was found to be $355 \mathrm{~nm}$ in fig. 3 .

Then, water was removed with the help of an evaporator and the copper(II)oxide nanoparticles were examined after they were dried at $70{ }^{\circ} \mathrm{C}$ for 72 hours. The changes in absorbance were measured to determine the optimum time in the sample taken with 10 minutes intervals from the reaction mixture prepared. The optimum time required to complete the reaction was determined to be 1 hour. The result of the analysis was given in Figure 4 . 


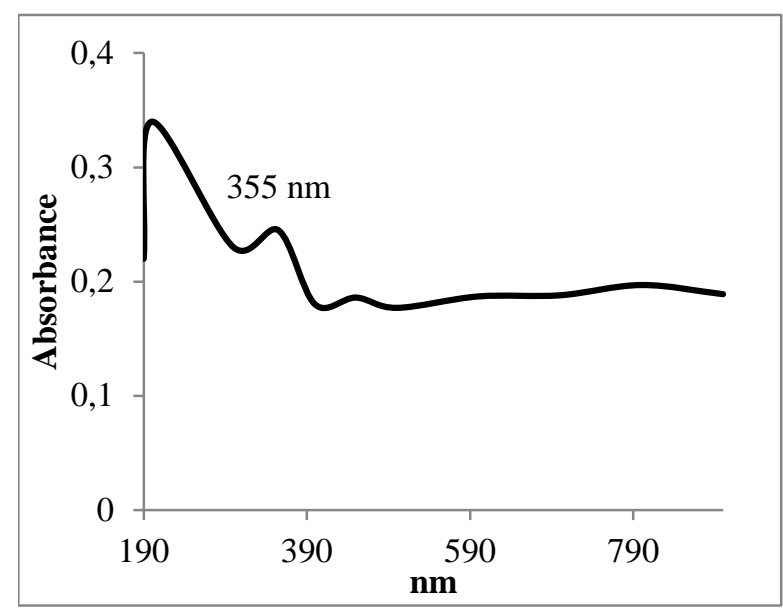

Figure 3. Wavelength-absorbance graph for copper(II)oxide nanoparticles

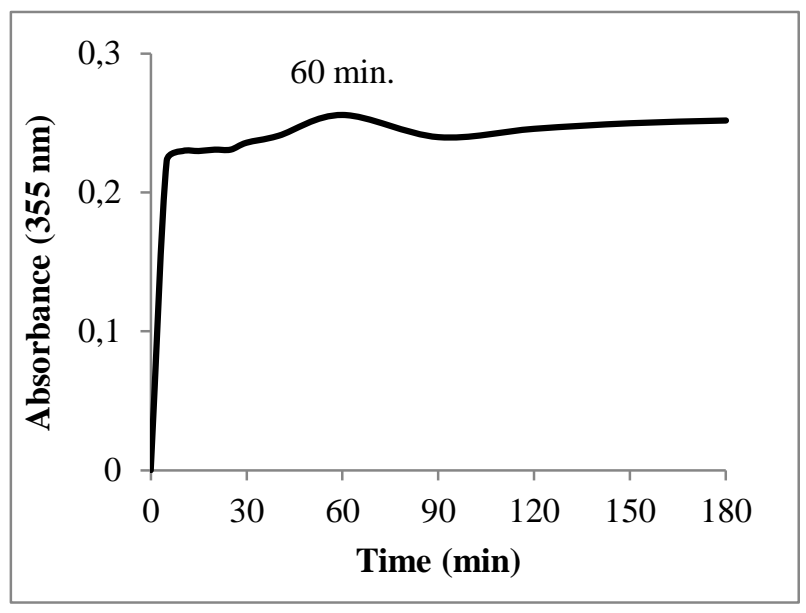

Figure 4. Absorbance diagram of copper(II)oxide nanoparticles versus time. $(\mathrm{pH}: 5$. temperature: 60 ${ }^{\circ} \mathrm{C}$ and concentration: $0.05 \mathrm{M}$ )

In order to determine the optimum $\mathrm{pH}$, the $\mathrm{pH}$ was varied from 3 to 10 at 8 different $\mathrm{pH}$ conditions. The obtained results were shown in Figure 5. As a result of experiments, we had determined that the optimum $\mathrm{pH}$ was 5 .
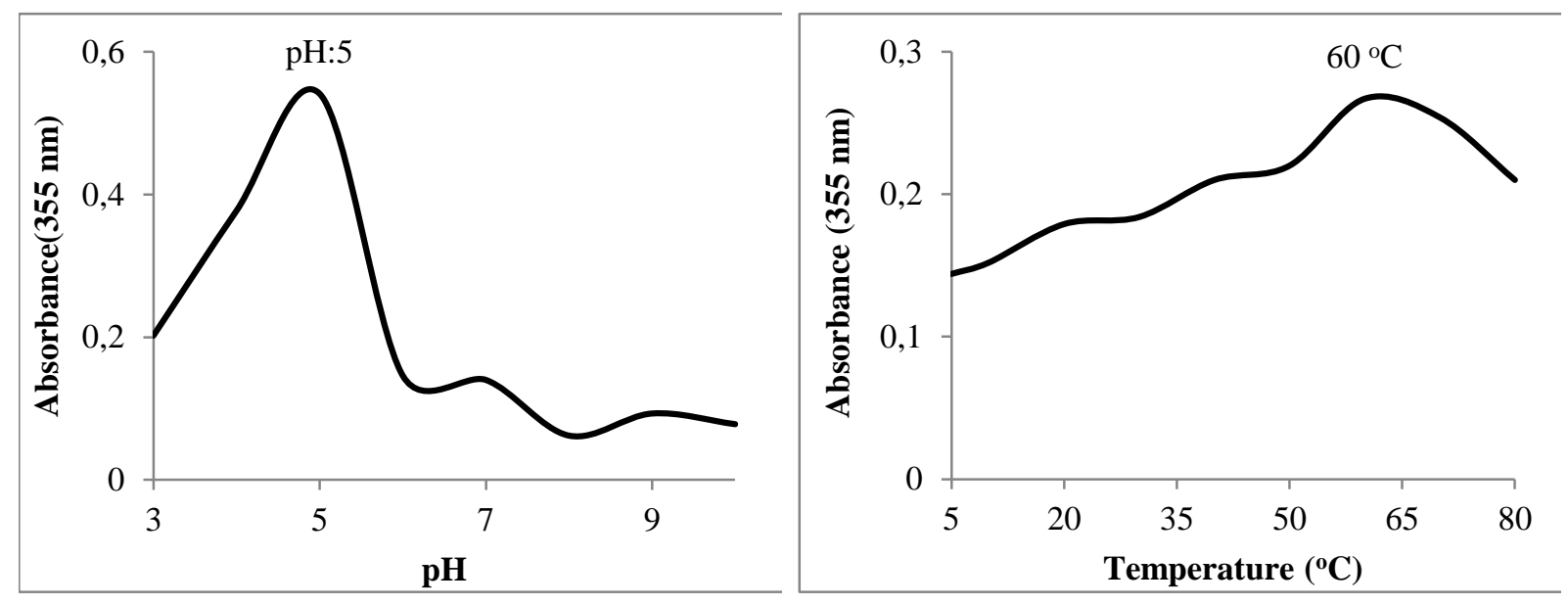

Figure 5. Absorbance graph of copper(II)oxide Figure 6. Absorbance graph of copper(II)oxide nanoparticles versus $\mathrm{pH}$ (time: $60 \mathrm{~min}$. temperature: nanoparticles versus temperature $\mathrm{pH}$ (time:60 min. $60{ }^{\circ} \mathrm{C}$ and concentration: $0.05 \mathrm{M}$ ). $\mathrm{pH}: 5$ and concentration: $0.05 \mathrm{M}$ ).

The absorbance-temperature graph was drawn with the results obtained from the experiments. The results of the processes were given in Fig 6. The graph showed that the optimal temperature for green synthesis was $60{ }^{\circ} \mathrm{C}$. The optimum metal ion concentration of the reaction was measured with a solution prepared at a concentration range of $4.10^{-1}-1.25 \cdot 10^{-2}$ $\mathrm{M}$ of $\mathrm{CuCl}_{2} \cdot 2 \mathrm{H}_{2} \mathrm{O}$. As a result of absorbance measurements at $355 \mathrm{~nm}$, the optimum concentration was found to be $0.05 \mathrm{M}$ in Figure 7. 


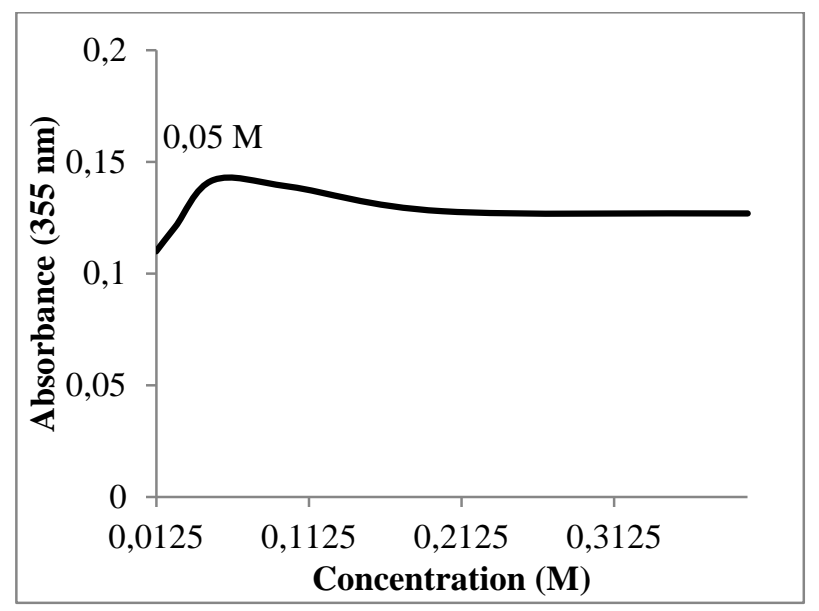

Figure7. Absorbance graph of copper(II)oxide nanoparticles versus concentration $\mathrm{pH}$ (time:60 min. temperature: $60{ }^{\circ} \mathrm{C}$ and $\left.\mathrm{pH}: 5\right)$.

Characterization of $\mathrm{CuO}$ nanoparticles synthesized by the green synthesis method was carried out the SEM chromatography (Figure 8). It was observed that the synthesized $\mathrm{CuO}$ nanoparticles according to SEM results are uniform spherical and are between 25-50 nm in size. This result showed that $\mathrm{Cu}_{2} \mathrm{O}$ nanoparticles synthesized from Erzincan Cimin grape extract are compatible with the values in the literature and can be classified as nanoparticles. EDX (energy dispersive $\mathrm{X}$-ray) chromatogram was shown the nanoparticles occurred from $\mathrm{Cu}$ and $\mathrm{O}$ molecules in Figure 9.

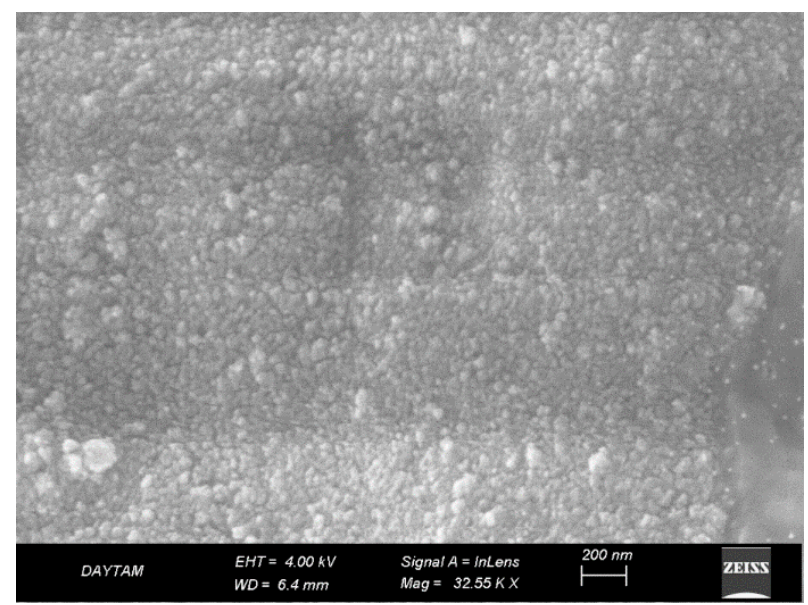

Figure 8. SEM chromatogram of copper (II) oxide nanoparticles

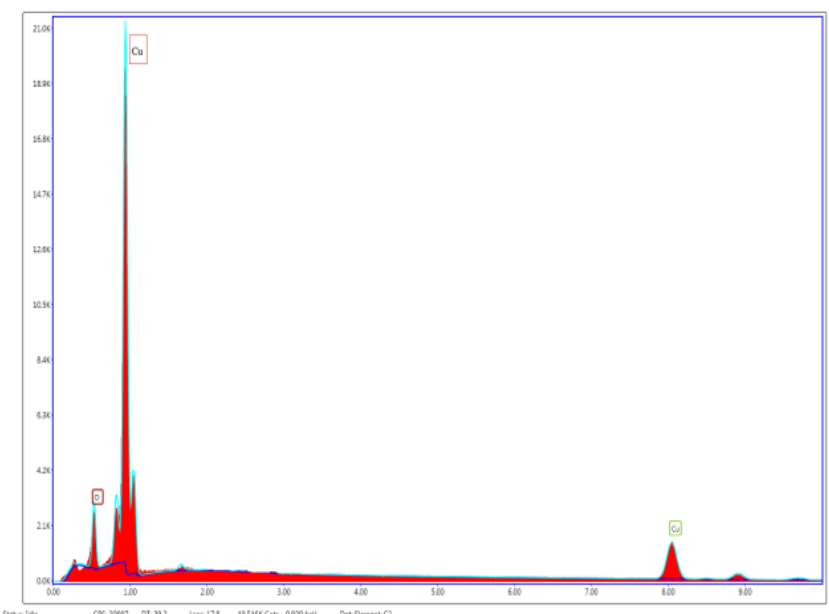

Figure 9. EDX chromatogram of copper (II) oxide nanoparticles. 
In the work of Azam and his group, the characteristic peaks were found to be (110), (111), (220) and (211) taken in the XRD chromatogram for $\mathrm{CuO}$ [17]. These results supported our experiments.

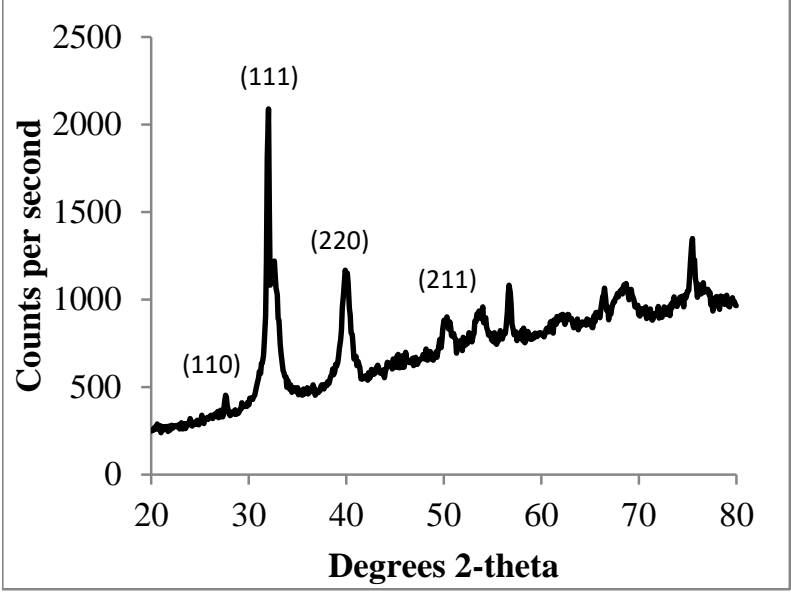

Figure 10. XRD chromatogram of copper(II)oxide nanoparticles

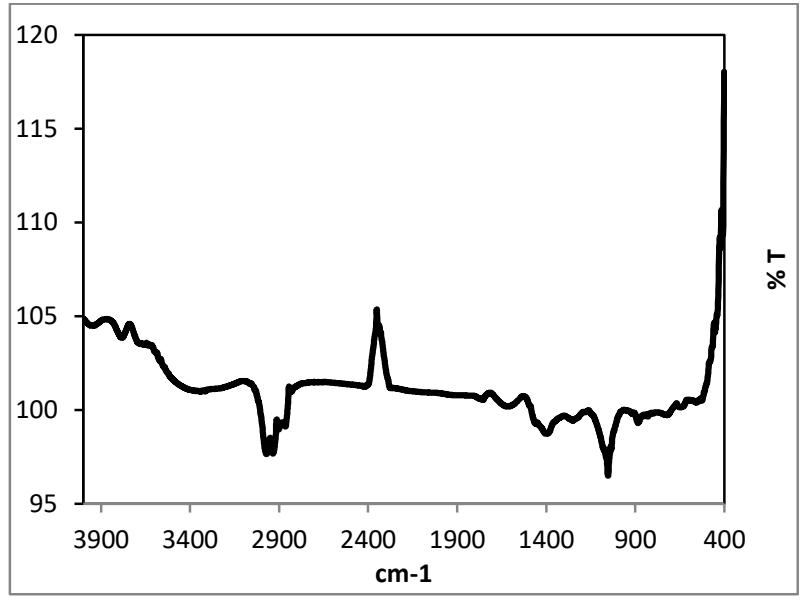

Figure 11. FTIR chromatogram of copper (II) oxide nanoparticles

FTIR spectrum was containing similar results before examination (18). The FTIR spectrum of grape extract mediated $\mathrm{CuO}$ nanoparticle shows that the broad absorption band at around $1650 \mathrm{~cm}^{-1}$ can be assigned to aromatic bending of alkene group $(\mathrm{C}=\mathrm{C})$. Absorption peak at $1060.0 \mathrm{~cm}^{-1}$ is stretching vibration of $\mathrm{C}-\mathrm{O}$ group of primary and secondary alcohols $(\mathrm{C}-\mathrm{O})$.

\section{CONCLUSIONS}

As a result of all these studies, copper(II)oxide nanoparticles have been synthesized with a new and unique method using plant extracts. For this purpose, Cimin grape extract which was an endemic species and grown in Erzincan region was used. As a result of the work, the nanoparticle synthesis has been proven by chromatographic measurements. The reaction conditions were optimized by the performed experiments. Since the $\mathrm{CuO}$ nanoparticles were obtained in a cheap, environmentally friendly and mild condition using the green synthesis method, the developed method could be easily applied. It was also thought that $\mathrm{CuO}$ nanoparticles might find widespread use in industry for dye removal, catalyst, biosensor development and antimicrobial agent synthesis.

\section{Conflict of Interests}

Authors declare that there is no conflict of interests.

\section{REFERENCES}

[1] Bhusan, S. H., Kumar, A. A., Ashish, T. F., \& Lal, K. M. (2012). Evaluation of Polyherbal formulation for diuretic activity in albino rats. Asian Pacific Journal of Tropical Disease, 2, S442-S445.

[2] Fan, P., \& Lou, H. (2004). Effects of polyphenols from grape seeds on oxidative damage to cellular DNA. Molecular and cellular biochemistry, 267(1-2), 67-74.

[3] Ismail, E. H., Khalil, M. M., Al Seif, F. A., \& El-Magdoub, F. (2014). Biosynthesis of gold nanoparticles using extract of grape (Vitis vinifera) leaves and seeds. Prog Nanotechnol Nanomater, 3, 1-12. 
[4] Singh, P. P., \& Bhakat, C. (2012). Green synthesis of gold nanoparticles and silver nanoparticles from leaves and bark of Ficus carica for nanotechnological applications. Int. J. Sci. Res. Pub, 2(5), 1-4.

[5] Konishi, Y., Ohno, K., Saitoh, N., Nomura, T., Nagamine, S., Hishida, H., ... \& Uruga, T. (2007). Bioreductive deposition of platinum nanoparticles on the bacterium Shewanella algae. Journal of biotechnology, 128(3), 648-653.

[6] Salam, H. A., Sivaraj, R., \& Venckatesh, R. (2014). Green synthesis and characterization of zinc oxide nanoparticles from Ocimum basilicum L. var. purpurascens Benth.-Lamiaceae leaf extract. Materials Letters, 131, 16-18.

[7] Liu, F. K., Huang, P. W., Chang, Y. C., Ko, F. H., \& Chu, T. C. (2004). Microwave-assisted synthesis of silver nanorods. Journal of materials research, 19(2), 469-473.

[8] Singh, A., Jain, D., Upadhyay, M. K., Khandelwal, N., \& Verma, H. N. (2010). Green synthesis of silver nanoparticles using Argemone mexicana leaf extract and evaluation of their antimicrobial activities. Dig J Nanomater Bios, 5(2), 483-489.

[9] Suramwar, N. V., Thakare, S. R., \& Khaty, N. T. (2013). One-Pot Green Synthesis of Ni Nanoparticles and Study of Its Catalytic Activity in the Hydrothermal Reduction of pNitrophenol. Synthesis and Reactivity in Inorganic, Metal-Organic, and Nano-Metal Chemistry, 43(1), 57-62.

[10] Park, B. K., Jeong, S., Kim, D., Moon, J., Lim, S., \& Kim, J. S. (2007). Synthesis and size control of monodisperse copper nanoparticles by polyol method. Journal of colloid and interface science, 311(2), 417-424.

[11]. Han, W. K., Choi, J. W., Hwang, G. H., Hong, S. J., Lee, J. S., \& Kang, S. G. (2006). Fabrication of $\mathrm{Cu}$ nano particles by direct electrochemical reduction from $\mathrm{CuO}$ nano particles. Applied Surface Science, 252(8), 2832-2838.

[12]. Zhu, H. T., Zhang, C. Y., \& Yin, Y. S. (2004). Rapid synthesis of copper nanoparticles by sodium hypophosphite reduction in ethylene glycol under microwave irradiation. Journal of Crystal Growth, 270(3), 722-728.

[13] Castangia, I., Marongiu, F., Manca, M. L., Pompei, R., Angius, F., Ardu, A., ... \& Ennas, G. (2017). Combination of grape extract-silver nanoparticles and liposomes: A totally green approach. European Journal of Pharmaceutical Sciences, 97, 62-69.

[14] Cicek, S., Gungor, A. A., Adiguzel, A., \& Nadaroglu, H. (2015). Biochemical evaluation and green synthesis of nano silver using peroxidase from Euphorbia (Euphorbia amygdaloides) and its antibacterial activity. Journal of Chemistry, 2015.

[15] Gültekin, D. D., Güngör, A. A., Önem, H., Babagil, A., \& Nadaroğlu, H. (2016). Synthesis of Copper Nanoparticles Using a Different Method: Determination of Its Antioxidant and Antimicrobial Activity. Journal of the Turkish Chemical Society, Section A: Chemistry, 3(3), 623-636.

[16] Lanje, A. S., Sharma, S. J., Pode, R. B., \& Ningthoujam, R. S. (2010). Synthesis and optical characterization of copper oxide nanoparticles. Adv Appl Sci Res, 1(2), 36-40.

[17] Azam, A., Ahmed, A. S., Oves, M., Khan, M. S., \& Memic, A. (2012). Size-dependent antimicrobial properties of $\mathrm{CuO}$ nanoparticles against Gram-positive and-negative bacterial strains. International Journal of Nanomedicine, 7, 3527.

[18] Saif, S., Tahir, A., Asim, T., \& Chen, Y. (2016). Plant mediated green synthesis of CuO nanoparticles: comparison of toxicity of engineered and plant mediated $\mathrm{CuO}$ nanoparticles towards Daphnia magna. Nanomaterials, 6(11), 205. 